\title{
UJI AKTIVITAS EKSTRAK METANOL DAUN BANDOTAN (Ageratum conyzoides Linn.) TERHADAP PENYEMBUHAN LUKA BAKAR PADA TIKUS PUTIH (Rattus norvegicus)
}

\author{
Rangga Hati Rabbu Igafur*, Welinda Dyah Ayu, Muhammad Amir Masruhim \\ Laboratorium Penelitian dan Pengembangan FARMAKA TROPIS \\ Fakultas Farmasi Universitas Mulawarman, Samarinda, Kalimantan Timur \\ *Email: ranggahati06@gmail.com
}

\begin{abstract}
ABSTRAK
Di Indonesia tanaman bandotan (Ageratum conyzoides Linn.) lebih dikenal sebagai tumbuhan liar (gulma) dikebun dan ladang. Tanaman ini dipercaya oleh masyarakat suku Dayak sebagai penyembuh luka dengan cara dikunyah atau dihancurkan dan kemudian ditempelkan pada luka. Penelitian ini dilakukan dengan tujuan untuk mengetahui aktivitas dari ekstrak metanol daun bandotan dalam menyembuhkan luka bakar. Hewan coba yang digunakan adalah tikus putih sebanyak 6 ekor, betina, berumur 2-3 bulan, dan bobot badan 100-200 g. Penelitian ini menggunakan 4 kelompok perlakuan. Luka bakar derajat II B dibuat dengan menggunakan plat logam berdiameter $1 \mathrm{~cm}$ yang dipanaskan dalam oven pada suhu $100^{\circ} \mathrm{C}$ selama 5 menit dan ditempelkan pada punggung tikus selama 5 detik. Perawatan dilakukan 2 kali sehari selama 21 hari yaitu K1 (gel), K2 (gel dan ekstrak 5\%), K3 (gel dan ekstrak 15\%), dan K4 (gel Bioplacenton). Hasil penelitian menunjukkan bahwa persen penurunan luas luka bakar kelompok K1 yaitu sebesar 57,74\%, K2 sebesar 64,98\%, K3 sebesar 61,47\% dan K4 sebesar 49,83\%. Berdasarkan hasil penelitian ini dapat disimpulkan bahwa kelompok K2 menunjukkan penyembuhan luka bakar yang lebih cepat daripada kelompok perlakuan lain.
\end{abstract}

Kata Kunci: Daun bandotan, Luka bakar, Gel

\begin{abstract}
Bandotan plant in Indonesia (Ageratum conyzoides Linn.), better known as wild plants (weeds) in the garden and fields. This plant is believed by the Dayak community as a wound healer by chewing or crushed and then placed on the wound. The ains of this research was to find activity of the methanol extract of bandotan leaf for burn healing. Experimental animals used were as much as 6 tails of Wistar strain rats, females, with the age of 2-3 months, and weighs 100-200 g. This experiments uses four treatment groups. The II B degree burns on the back of rats made using a $1 \mathrm{~cm}$ diameter metal plate that is heated in an oven at $100{ }^{\circ} \mathrm{C}$ for 5 minutes and placed on the backs of mice for 5 seconds. Treatment was done 2 times a day for 14 days, K1 (gel), K2 (gel and extract 5\%), K3 (gel and extract 15\%) and $K 4$ (gel Bioplacenton). The results showed that the percent decrease in the burn area K1 group that was to $57.74 \%$, K2 was to $64.98 \%$, K3 was to $61.47 \%$ and $K 4$ was to $49.83 \%$. It can be concluded that the K2 group showed healing of burns faster than other treatment groups.
\end{abstract}

Key words: Bandotan leaf, Burn healing, Gel 


\title{
PENDAHULUAN
}

Segala aktivitas dalam kehidupan sehari-hari dapat menimbulkan resiko luka pada tubuh salah satunya luka bakar. Luka bakar adalah bentuk kerusakan jaringan yang disebabkan kontak dengan sumber panas seperti api, air panas, bahan kimia, listrik dan radiasi (Moenadjat, 2003).

Penyembuhan luka dapat terjadi melalui proses alamiah dari tubuh itu sendiri, namun sering kali diberikan juga pemberian obat-obatan untuk mempercepat proses penyembuhan luka. Obat-obatan yang digunakan adalah obat sintetik yang umumnya relatif mahal. Oleh karena itu, banyak masyarakat yang beralih ke obat alami yang berasal dari tumbuhan karena selain memiliki efek samping yang kecil juga tidak memrlukan biaya yang mahal karena dapat langsung digunakan dari tumbuhan itu sendiri.

Tanaman bandotan (Ageratum conyzoides Linn.) berasal dari Amerika tropis. Di Indonesia merupakan tumbuhan liar dan lebih dikenal sebagai tumbuhan pengganggu (gulma) di kebun dan ladang. Tanaman ini dipercaya oleh masyarakat suku Dayak sebagai penyembuh luka dengan cara dikunyah atau dihancurkan dan kemudian ditempelkan pada luka. Menurut Amadi dkk. (2012) dalam penelitiannya mengidentifikasi senyawa metabolit sekunder yang terdapat pada tanaman andotan khususnya pada bagian daun diperoleh hasil bahwa tanaman bandotan mengandung senyawa alkaloid, flavonoid, tanin, saponin, asam sianida, fenol dan senyawa metabolit sekunder lainnya. Menurut Dash dan Murthy (2011) dalam penelitiannya ekstrak metanol daun bandotan yang sebelumnya sudah diidentifikasi mengandung senyawa alkaloid, tanin, senyawa fenolik dan flavonoid ternyata efektif dalam menyembuhkan luka sehingga dilakukan pengujian terhadap ekstrak metanol daun bandotan untuk mengetahui aktivitasnya dalam menyembuhkan luka bakar pada tikus putih.

\section{METODE PENELITIAN}

\section{Bahan}

Alkohol 70\%, aquadest, daun bandotan, lidokain $\mathrm{HCl}$, metanol, carbopol 940, catoon bud, kasa steril, kertas saring, kertas kalkir dan gel Bioplacenton.

\begin{abstract}
Alat
Alat pencukur, batang pengaduk, cawan porselen, corong porselen, desikator, gelas kimia, labu ukur, hot plate, mangkuk kaca, mortir, stamper, pipet tetes, gunting, penggaris, rotary evaporator, plat logam, oven, spoid, timbangan digital, toples kaca dan waterbath.

\section{Prosedur}

Hewan coba yang digunakan pada penelitian ini yaitu tikus putih galur Wistar, jenis kelamin betina, umur 2-3 bulan dan berat badan 100-200 gram. Kriteria tikus sehat ditandai dengan gerakan aktif, bulu bersih, mata jernih, dan belum pernah mendapatkan pengobatan sebelumnya. Tikus putih digunakan sebanyak 6 ekor dilakukan randomisasi kemudian ditempat dalam kandang terpisah sesuai dengan jumlah perlakuan. Seriap kandang berisi 2 ekor tikus, dadaptasikan selama 7 hari dan pada hari ke- 8 dilakukan pemberian luka bakar derajat II B. Tikus diberi pakan standar dan minum secara ad libitum. Pembuatan ekstrak dilakukan dengan menyiapkan 600 gram daun bandotan dikumpulkan dan dipisahkan dari pengotor lain seperti tanah, bagian bukan daun atau bagian tanaman yang rusak serta dicuci bersih. Selanjutnya dibuat simplisia dan diekstraksi dengan metode maserasi menggunakan pelarut metanol selama beberapa hari dengan sesekali dlakukan pengadukan. Kemudian hasil maserasi dipekatkan dengan rotary evaporator hingga diperoleh ekstrak kental lalu diletakkan diatas waterbath dan
\end{abstract}


dimasukkan kedalam desikator hingga diperoleh ekstrak kering. Pengujian ekstrak bebas pelarut organik harus dilakukan untuk memastikan ada tidaknya kandungan pelarut organik pada ekstrak daun bandotan dengan menggunakan metode uji Iodoform.

Sebelum pengujian luka bakar pada tikus putih, dilakukan terlebih dahulu pembuatan basis gel yang terdiri dari campuran antara aquadest dan Carbopol 940. Kemudian dibuat ekstrak dengan konsentrasi 5\% dan 15\% dengan cara mencampurkan ekstrak dengan basis gel. Lokasi pemberian luka bakar pada kedua bagian pungung tikus yaitu punggung bagian kiri dan kanan. Bulu dicukur dan dibuat area berbentuk persegi dengan ukuran $3 \times 3 \mathrm{~cm}$ disekitar kulit yang akan dibuat luka bakar, kulit didesinfeksi terlebih dahulu dengan alkohol $70 \%$. Dilakukan anestesi pada punggung tikus dengan menggunakan lidokain HCL secara intrakutan yang sebelumnya dikonversi dahulu dosisnya terhadap tikus putih. Luka bakar dibuat dengan cara menempelkan plat logam stainless berdiameter $1 \mathrm{~cm}$ yang dipanaskan didalam oven suhu $100^{\circ} \mathrm{C}$ selama 5 menit dan ditempelkan pada punggung tikus selama 5 detik hingga terbentuk luka bakar derajat II yang ditandai dengan adanya warna kemerahan dan terbentuknya bula (gelembung air) pada kulit tikus.

Tikus yang sudah dilukai pada bagian pungungnya diberi perawatan berdasarkan kelompoknya. Kelompok kontrol negatif (K1) dioleskan basis gel, kelompok uji 1(K2) dioleskan ekstrak dengan konsentrasi 5\%, kelompok uji 2 (K3) dioleskan ekstrak dengan konsentrasi 15\%, dan kelompok kontrol positif (K4) dioleskan gel Bioplacenton. Pe ngolesan dilakukan sebanyak 2 kali sehari yaitu pagi dan sore hari. Perawatan dilakukan mulai dari hari ke-1 hingga hari ke-14 (selama 2 minggu). Luka bakar dirawat secara tertutup dengan menggunakan kasa steril dan diamati kecepatan penyembuhan luka dengan melihat penurunan luas luka setiap hari. Selanjutnya dihitung presentase kecepatan penyembuhan luka dengan menggunakan rumus :

$\mathrm{Px}=\frac{\mathrm{L}_{1}-\mathrm{L}_{\mathrm{x}}}{\mathrm{L}_{1}} \times 100 \%$

Keterangan :

$\mathrm{P}_{\mathrm{x}}=$ Presentase penyembuhan luka bakar hari ke- $\mathrm{x}$

$\mathrm{L}_{1}=$ Luas luka bakar hari pertama

$\mathrm{L}_{\mathrm{x}}=$ Luas luka hari ke- $\mathrm{x}$

\section{HASIL DAN PEMBAHASAN}

Dari hasil ekstraksi simplisia daun bandotan, diperoleh persen rendemen ekstrak yaitu sebagai berikut:

Tabel. 1. Persen Rendemen Ekstrak

\begin{tabular}{lc}
\hline Berat sampel segar & 600 gram \\
Berat sampel kering & 249 gram \\
Berat ekstrak kering & 42.2 gram \\
\hline \multicolumn{1}{c}{ Persen Rendemen Ekstrak } & Jumlah \\
\hline Rendemen ekstrak kering terhadap sampel segar & $7.03 \%$ \\
Rendemen ekstrak kering terhadap sampel kering & $16.94 \%$ \\
Rendemen sampel kering terhadap sampel segar & $41.5 \%$ \\
\hline
\end{tabular}

Berdasarkan hasil pengamatan luas luka bakar pada tikus putih selama 14 hari (2 minggu) dengan membandingkan 4 kelompok perlakuan yaitu kelompok K1 (kontrol negatif) yang 
diberi perawatan luka bakar dengan basis gel, kelompok K2 (uji 1) yang diberi perawatan luka bakar dengan gel ekstrak konsentrasi 5\%, kelompok K3 (uji 2) yang diberi perawatan luka bakar dengan gel ekstrak konsentrasi 15\% dan kelompok K4 (kontrol positif) yang diberi perawatan luka bakar dengan gel Bioplacenton diperoleh data sebagai berikut.

Tabel. 2. Presentase Luas Luka Bakar

\begin{tabular}{ccccc}
\hline \multirow{2}{*}{ Hari ke- } & \multicolumn{4}{c}{ Luas Luka Bakar } \\
\cline { 2 - 5 } & Kontrol (-) & Ekstrak 5\% & Ekstrak 15\% & Kontrol (+) \\
\hline 1 & $0 \%$ & $0 \%$ & $0 \%$ & $0 \%$ \\
2 & $-43.91 \%$ & $-2, .3 \%$ & $4.15 \%$ & $-19.73 \%$ \\
3 & $-30.20 \%$ & $-7.58 \%$ & $3.22 \%$ & $-40.63 \%$ \\
4 & $-30.17 \%$ & $9.43 \%$ & $0.33 \%$ & $-21.41 \%$ \\
5 & $9.55 \%$ & $22.74 \%$ & $22.94 \%$ & $-3.18 \%$ \\
6 & $11.50 \%$ & $23.17 \%$ & $33.45 \%$ & $-0.37 \%$ \\
7 & $29.16 \%$ & $38.97 \%$ & $39.59 \%$ & $9.08 \%$ \\
8 & $25.70 \%$ & $42.61 \%$ & $28.94 \%$ & $21.56 \%$ \\
9 & $29.22 \%$ & $38.02 \%$ & $32.80 \%$ & $33.70 \%$ \\
10 & $49.00 \%$ & $45.22 \%$ & $35.63 \%$ & $36.12 \%$ \\
11 & $44.85 \%$ & $46.07 \%$ & $44.19 \%$ & $32.28 \%$ \\
12 & $41.92 \%$ & $59.18 \%$ & $51.50 \%$ & $33.18 \%$ \\
13 & $57.64 \%$ & $64.94 \%$ & $49.27 \%$ & $50.01 \%$ \\
14 & $57.94 \%$ & $64.98 \%$ & $61.47 \%$ & $49.83 \%$ \\
\hline
\end{tabular}

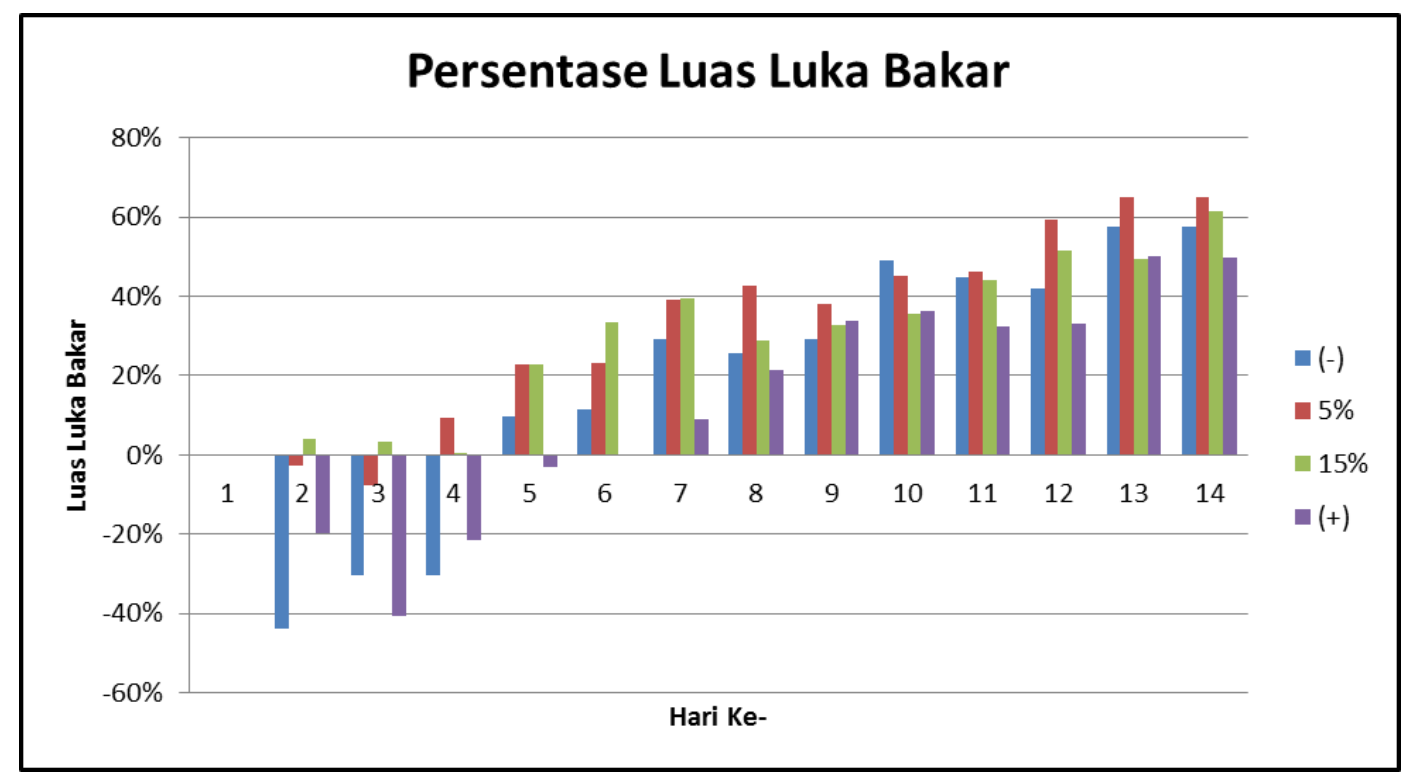

Grafik. 1. Presentase Luas Luka Bakar

Dari data hasil pengamatan diatas, terlihat bahwa terjadi peningkatan luas luka pada hari ke-2 yang ditandai dengan nilai minus dari persen luas luka bakar. Akan tetapi mulai dari hari ke-4 terjadi penurunan luas luka bakar hingga hari ke-14. Dari data tersebut kelompok kontrol negatif mengalami peningkatan luas luka yang paling besar dibandingkan kelompok lain. Menurut Kee (1996) hal itu terjadi karena reaksi inflamasi 
yang umumnya berlangsung sejak terjadinya luka hingga hari ke-3. Proses inflamasi merupakan suatu mekanisme perlindungan dimana tubuh berusaha untuk menetralisir dan membasmi agen-agen yang berbahaya pada tempat cedera dan untuk mempersiapkan keadaan untuk perbaikan jaringan. Perawatan luka dilakukan dengan cara mengoleskan ekstrak secara topikal dengan tujuan mendapatkan kesembuhan secepat mungkin sehingga jumlah jaringan fibrosis yang terbentuk akan sedikit dan demikian mengurangi jaringan parut. Diusahakan juga pencegahan terjadinya peradangan yang merupakan hambatan paling besar terhadap kecepatan penyembuhan. Dari kedua variasi konsentrasi yang diujikan (5\% dan 15\%) jika dibandingkan dengan kontrol negatif maka konsentrasi 5\% yang paling baik dalam menyembuhkan luka dalam pengamatan yang dilakukan setiap hari selama 14 hari (2 minggu) dimana kontrol negatif, konsentrasi 5\%, konsentrasi $15 \%$ dan kontrol positif mempunyai nilai persen penyembuhan luka bakar berturut-turut yaitu sebesar $57.94 \%, 64.98 \%, 61.47 \%$ dan $49.83 \%$.

\section{KESIMPULAN}

Berdasarkan hasil penelitian yang telah dilakukan, dapat disimpulkan bahwa ekstrak metanol daun bandotan pada konsentrasi 5\% memiliki aktivitas yang paling baik dalam menyembuhkan luka bakar pada tikus putih dengan nilai persen penurunan luas luka bakar sebesar $64.98 \%$.

\section{DAFTAR PUSTAKA}

1. Ansel, H.C. 1989. Pengantar Bentuk Sediaan Farmasi ed. 4. UI-PRESS: Jakarta.

2. Amadi, B. A., Duru M. K. C., and Agumuo, E. N. 2012. Chemical Profiles of Leaf, Stem, Root, and Flower of Ageratum conyzoides. Asean Journal of Plant Science and Research. Vol. 2. No. 4. Halaman: 429.

3. Dash, Gouri K and Murthy, P. Narasimha. 2011. Wound Healing Effects of Ageratum conyzoides Linn. International Journal of Pharma and Bio Science. Vol. 2. No. 2. Halaman: 371.

4. Kee, Joyce L. 1996. Pendekatan Proses Keperawatan. EGC: Jakarta.

5. Moenadjat, Yefta. 2003. Luka Bakar: Pengetahuan Klinik Praktis. Balai Penerbit FKUI: Jakarta. 